\title{
State-owned enterprise reform
}

\section{Yiping Huang *}

China's agricultural sector was the first to experience significant success from reform, but initial reform efforts in the late 1970s were directed at state-owned enterprises (SOEs). In 1978, when farmers started to experiment-secretly and illegally-with the now famous household responsibility system (HRS) in several villages in Anhui province, the government was already introducing the first set of policy experiments with SOEs in Sichuan province and then in other places in the following years. The government's rationale for focusing on reform was obviousthe state sector dominated the Chinese economy in terms of both production and urban employment, so it was logical to think that the success of reform would be based on the smooth transformation of SOES.

The path of SOE reform in the following two decades, however, was far more complicated than that of agricultural reform. In many years during the reform period, especially in the early 1990s, SOE reform was assigned top policy priority but failed to achieve policy objectives fully. After twenty years, SOE reform is still one of the most difficult tasks facing the Chinese government.

The state sector experienced significant changes during the reform period. On the one hand, the state sector expanded significantly. Output of industrial SOEs grew at 6.5 per cent per annum between 1978 and 
1997 which, though lower than gross domestic product (GDP) growth, was respectable by any standard. The net value of capital stock (at current prices) rose by 16 per cent per annum between 1985 and 1997, while total employment first increased steadily and then stagnated. The state sector remains the major contributor to government revenue. On the other hand, the relative importance of the state sector declined sharply. The share of SOEs in the country's industrial output dropped from 78 per cent in 1978 to 27 per cent in 1997 . SOEs now only dominate in a handful of industries such as oil and gas mining and processing, transportation equipment manufacturing, and electricity and water. The share of all state-owned units in urban employment also declined, but at a much slower rate, from 78 per cent in 1978 to 63 per cent in 1997.

The reform tasks were (and remain) more complicated in the state sector. Old problems such as lack of incentive and production inefficiency remain, and new problems have arisen, such as forfeiture of state assets and a rise in loss-making. These become increasingly heavy burdens on the economy through their impact on the government budget, the financial sector and the efficiency of resource allocation. When Zhu Rongji announced his dramatic reform plans in early 1997, including completion of SOE reform within three years, even with the anticipation of possible 'landmines and abysses' ahead the Chinese government already had problems. The government realised that it could no longer nurture the inefficient SOEs without seriously compromising prospects for the Chinese economy.

A review of past reform experiences and their impact is no easy task since SOE reform in China has been such a controversial subject in the literature. Economists disagree on almost everything, ranging from the effectiveness of past policies to the direction of future reform (see Table 5.1). There are two opposing judgments about SOE productivity performance during the reform period. While some economists believe that productivity growth was significant, others present cases for stagnant or even negative productivity growth. There is no disagreement about the worsening financial performance of SOEs. Some economists attribute increased loss-making to increased market competition, others suggest that undisciplined spending behaviour of the enterprises is a more significant cause. China's gradual approach to reform has generally 
been approved of by academics given its favourable outcomes in comparison with the reforms in Eastern Europe and the former Soviet Union (EEFSU).

The exact contributions made by SOEs are, however, not clear. Some economists believe the importance of SOEs lay in their role as a safety net, and the role that the safety played in the smooth progress of other reforms; others point to the increasing burdens imposed by SOEs on the macroeconomy, including fiscal deficits, a weak financial sector and macroeconomic instability. Most economists believe that privatisation is a necessary step in the transformation of the state sector. But there are also strong arguments among Chinese economists that ownership is not a necessary condition for efficient firms and that SOEs can perform efficiently if they are provided with a fair and competitive market environment.

\section{Table 5.1 Controversies about China's state sector reform}

Issue 1: Productivity performance

Argument I Total factor productivity growth was significant

Argument II Productivity stagnated

Issue 2: Causes of rising loss-making

Argument I Increased competition was the dominant factor Argument II Over-spending on wages was a more significant cause

Issue 3: Macroeconomic contribution

Argument I The state sector served as a safety net for China's reform

Argument II The state sector was an important macroeconomic destabiliser

Issue 4: Importance of privatisation

Argument I SOEs can perform efficiently in a fair and competitive market

Argument $\|$ Privatisation is an inevitable reform step 


\section{Reform experiences}

A small group of outspoken Chinese economists began to voice ideas about reforming the SOE system from as early as the late 1950s. In a paper first published in 1957, Gu Zun pointed out that the root of the inefficiency problems of the SOE sector and the whole Chinese economy lay in the implementation of central planning and the government's direct intervention in enterprise management (Gu 1957). He recommended that compulsory production plans and state prices be abolished to leave prices freely floating; that returns to workers in an enterprise be linked with its profitability; and that SOEs make production decisions according to changes in prices. In 1961, Sun Yefang also suggested that enterprise operation should be left to managers, while the state plan should focus on new investment (Sun 1961). He further argued that profits should be taken as the core indicator of enterprises' performance. ${ }^{\prime}$

Reform of the SOE sector was seen as one of the most important challenges once reform had begun. The reformist economists reached a consensus that the SOEs must be transformed from administrative units to independent economic identities. Xue (1981) argued that SOE reform was the most important of the two problems urgently requiring solution in economic reform, and that the objective of reform was to transform SOEs into truly live economic management units. Dong (1985) proposed that one crucial task of economic reform was to make SOEs relatively independent commodity producers. Jiang (1980) argued for an 'enterprise-based economy' in which enterprises should have independent management and accounting under state leadership and monitoring. He even recommended that reform should grant SOE workers a corporate interest in their firms.

Detailed reform measures proposed at that stage focused almost exclusively on expanding enterprise autonomy and sharing profits between the state and enterprises. Reform programs drafted by 'think tank' groups were almost all related to enterprise autonomy, with complementary reforms in prices, taxation, and planning to follow later (Naughton 1995). Ideas of creating incentives for SOEs were reflected in proposals for both profit-retention at the enterprise level and floating wage rates at the employee level. As noted by Wu (1993b) and Naughton (1995), these early discussions and proposals were heavily influenced by the Yugoslav-style worker management model. 


\section{The responsibility system}

China's SOE reform was started in Sichuan province where, in October 1978 , a program of expanded enterprise autonomy was introduced to six factories. The experiment defined that, after fulfilling state plans, these SOEs would have certain flexibilities in deciding about production plans, product marketing, worker employment and technological innovation. They would also share the profits according to specified plan and above-plan profit retention rates. The number of SOEs experimenting with this new system increased to 100 in Sichuan province from the beginning of 1979 . Because the above-plan profit retention rate was higher than the plan rate, this system also had the potential to punish previously more profitable firms. From 1980, the provincial government also started to adopt a unified profit retention rate. At the same time, there were also experiments with changing profit remittances to taxes in some SOEs.

Learning from the experiences in Sichuan province, the central government began its own program in eight firms in Beijing, Tianjin and Shanghai from May 1979. The content of this program was similar to that of Sichuan. In July that year, the central government announced a new responsibility system for profits and losses, the core of which was that SOEs would have the right to retain a share of profits, enjoy accelerated depreciation and have the right to sell above-plan output ( $X \mathrm{U}$ and Li 1996). By June 1980, the number of SOEs adopting this responsibility system had risen to 6,600 , accounting for about 16 per cent of SOEs, 60 per cent of SOE output and 70 per cent of SOE profits. In early 1981, about 42,000 SOEs chose the system of 'responsibility for profits and losses'. By 1983, almost all SOEs had adopted this responsibility system. In May 1984, in an effort to consolidate and improve the responsibility system, the government further expanded SOEs' decision-making rights in nine areas including production planning, raw material purchasing, product marketing, allocation of retained funds, determination of wages and bonuses, cross-region and cross-industry cooperation, employee recruitment and appointment of middle level managers, disposition of redundant assets, and exporting (Xu and Li 1996). In September 1985, the state further announced that SOEs could determine their production structure according to market demand and enterprises' comparative advantages, conditional on fulfilment of state plans. 
To complement the reforms, autonomy and incentive, two steps of 'tax for profit' reforms were carried out. In February 1983, a reform experiment was introduced in a number of SOEs, such that they would no longer pay fees for usage of fixed assets and working capital but would pay a 55 per cent tax on their total profits. The after-tax profits, however, were still shared by the state and the enterprises in certain proportions. The proportion of after-tax profit remittance was calculated from their 1982 performance. This was called the first step of 'tax for profit'. The second step of 'tax for profit' was introduced in September 1984 , the main purpose of which was to replace the previous co-existence of tax and profit remittance with a simple tax system. Enterprises were to adopt 'four taxes and two fees': annual fees for fixed assets and working capital financed from budgetary grants, a 50 per cent income tax, taxes on real estate, vehicle tax and adjustment tax.

Meanwhile, the '(repayable) loan for (free) grants' reform was also initiated. A few experimental projects were set up in November 1979. At the end of 1984, a decision was made that all state investment would be on a repayable basis, allocated through the state banking system.

Implementation of the responsibility system and associated reforms was crucial to providing both autonomy and incentives to the enterprises, and achieved at least partial success. But there were a number of problems. First, at a time when the central plan still controlled a dominant proportion of SOEs' activities, enterprises could hardly exercise autonomy. The objectives of the state plan and the SOEs were often different; when they were in conflict the state would intervene in enterprise management (Wu 1993b). From the point of view of the government, if prices were seriously distorted, managers could not achieve optimal resource allocation even when they had the freedom to make production decisions. This provided further reasons for state intervention. SOEs, therefore, remained effectively subordinated to the bureaucratic apparatus and continued to be bound by the overlapping control mechanisms (Naughton 1995).

Second, the reforms actually provided little incentive to SOEs. The reform of 'bank loans for budgetary grants' did not succeed because state banks could not effectively force unprofitable SOEs to repay their loans. The system after the first step of 'tax for profit' was rather complicated and often left the SOEs with very little retained profit, while 
the second step of 'tax for profit' implied that profitable enterprises ended up with relatively low marginal retention rates because of the adjustment tax. Within SOEs, relaxation of state controls over wages and, especially, bonuses in the early 1980 s helped to steadily raise workers' incomes and living standards. But in terms of reforming the incentive mechanism, the impact of these policy changes was very limited.

Third, the early reforms did not define clearly the responsibilities of SOEs after the autonomy was expanded, apart from 'responsibility for profits or losses' (which was again difficult to enforce under the circumstances). This became a concern because, if not properly disciplined, managers and employees would engage in opportunistic behaviour for short-term benefits and might act against the long-term interests of the enterprises. Overspending on wages and bonuses, for instance, was widely observed during the reform period (Lin et al. 1997; Sachs and Woo 1997).

\section{The contract system}

Policy discussions in the mid 1980s turned to enhancing the responsibility component of the responsibility system and a number of proposals were put forward including the contract system, the shareholding system, the asset responsibility system and others such as leasing and bankruptcy. At the time the debate was most intense between proponents of the contract system and the shareholding system. Supporters of the contract system argued that, while maintaining state ownership, SOEs would perform efficiently with clearly defined responsibilities, rights and benefits of both the state and the enterprises by contracts (Yang 1990). Proponents of the shareholding system argued that it was a matured enterprise institution after 200 years of development in market economies. The shareholding system could solve completely the problem of inseparability between government administration and enterprise business and promote optimal resource allocation ( $\mathrm{Li}$ 1987). The 'asset responsibility system' recommended consisted of three important aspects: asset evaluation, return sharing and asset responsibility. This new system was intended to solve the problems of incomplete information and the 'soft-budget' constraint (Hua et al. 1986). 
State-owned enterprise reform in the second half of the 1980s was dominated by the implementation of the contract system. A limited number of SOEs also experimented with the other proposals. The reason for the wide introduction of the contract system at that time was partly because it maintained state ownership, so politically it was more feasible, and partly due to the encouragement of the success in rural China. It was implemented against a background of industrial recession in 1986 (Dong and Tang 1992). The responsibility system and the contract system have some common elements, but the latter was an improvement on the basis of the former. The contract system emphasised the 'responsibilities' of the enterprises while retaining the rights and incentives of the responsibility system. The contract system was also more stable: contracts were often signed for three to five years.

In December 1986, the government announced a new policy encouraging adoption of the contract system (Xu and Li 1996). By the end of 1988, about 93 per cent of SOEs had adopted various forms of the contract system. There were five main types of contracts at that time. The first type specified that the contractors must guarantee profit remittances, technological transformation and, sometimes, compulsory plans, while the firms' total wage bills were linked to their profitability. It required the contractors to remit the quota profit regardless of the firms' financial performance. ${ }^{2}$ The second type required that enterprises, after paying taxes, had to remit a fixed amount of profit, which increased over time according to an agreed growth rate. The difference between the third type and the second was that the base quotas for profit remittances were fixed over time, but the firms had to share the extra profits with the state based on a retention rate. The fourth type of contract was specifically for loss-making enterprises and set targets of fixed amounts of losses to be subsidised by the state each year. The fifth type of contract emphasised input-output relations and was applied completely to the industries of oil, coal, iron and steel, railway, post and communications, chemical and civil aviation.

At the same time, other forms of enterprise institutions were also under experimentation. In November 1984, one SOE in Shanghai issued shares to the public. In December 1986, seven SOEs in Shanghai formed a shareholding company that was dominated by the state. Other firms in Shanghai also made progress in this direction. Meanwhile, from the mid 1980 s, a limited number of small SOEs were leased to collectives 
or individuals. ${ }^{3}$ It was reported that by the end of 1987 , about 46 per cent of the small SOEs had been contracted or leased (Xu and Li 1996).

These reforms had some positive impacts on SOEs' performance (Xu and Li 1996), but overall they still did not achieve the objective of turning SOEs into efficient enterprises. The contract system had a number of problems. First, it did not guarantee that SOEs became independent economic identities. Enterprise managers' decisions could be overturned by the state or their supervisory agents, especially with respect to investment and employment. The intervention was in some cases strengthened because the state had the final decision on who would get the contract (Wu 1993b). Second, negotiation of the contracts was extremely difficult. Not only were the two negotiating parties, the state and the contractors, in unequal positions, but also the state lacked necessary information about the operation of the enterprises. Contract terms thus depended significantly on the negotiation process itself. It was even suggested that the contracts were often the outcome of administrative arrangements (Zhou et al. 1994). Third, the contracts were often easy to realise when firms performed well, but very hard to implement when firms could not meet the quota for profit remittances. The contract was thus weak as a discipline for governing contractors. ${ }^{4}$ Fourth, the contract did not solve the short-term behavioural problems of the managers and employees. Their behaviour was still driven by short-term motivations, impinging on the interests of the owner, the state, and damaging firms' long-term development (Huang et al. 1997a). Other explanations were also given for the lack of success of the contract system including lack of a monitoring mechanism, incompleteness in expanding enterprise autonomy, and lack of separation between government administration and enterprise management. In 1991 and 1992, many SOEs had difficulties in renewing or settling new contracts (Dong and Tang 1992).

Why then was the contract system so successful in the countryside but so problematic in the state sector? There are a number of differences between the rural and urban systems to account for the different performance. First, after the household responsibility system was implemented in the countryside, agricultural production was managed by individual households. Management among family members, often by the household head, is relatively easy; management of an SOE with hundreds and even thousands of employees is relatively more 
complicated. Second, the farm household receives the residual return from land after fulfilling agricultural taxes, state purchase quotas and collective levies. All these remittances are fixed in either quantities or in values and thus there is no need to monitor farm households' operations. Monitoring of SOEs is difficult but critical, considering the possibility of managers manipulating information for either reduced remittances or increased subsidies (Dong and Tang 1992). Third, while the revenue from SOEs has always been an important component of the government budget, the revenue from the agricultural sector was minimal. The probability of government intervention was thus much higher in the SOE sector than the agricultural sector. Finally, the length of contracts was different. In the agricultural sector, the contract term was for 15 years to begin with and later extended for a further 15 years; the initial length of contracts for SOEs was between three and five years. The short-term performance of the household responsibility system and the SOE contract system is very different. However, they share a common longterm problem: contractors' lack of interest in investment for long-term development.

\section{The shareholding system and privatisation}

In the early 1990s, the key words in China's discussion of SOE reform were autonomy and monitoring. Monitoring became a new focus because it was recognised that enterprises would hardly fulfil their full responsibilities if there was no effective monitoring (Lin et al. 1997; Zhang 1995). Economists focusing on autonomy argued that the lack of success in the SOE sector was mainly because the enterprises did not enjoy sufficient autonomy in decision-making. They sought to solve the issue of autonomy either through further expansion of enterprise autonomy or property rights reform. Economists focusing on monitoring argued that under the current regime SOEs would not perform efficiently without effective monitoring, even with sufficient decision autonomy. They sought to solve the monitoring problem through either property rights reform or the establishment of modern enterprise institutions. In short, economists could be divided into three groups according to their recommendation for further reforms-those supporting the expansion of enterprise autonomy, those supporting improvement of the internal corporate governance, and those supporting the establishment of a competitive environment. 
The enterprise autonomy group pledged that full decision autonomy was a necessary and sufficient condition for SOEs to be efficient. It pointed particularly to the administrative intervention in enterprise decisions. Liu (1996) argued that the continued lack of autonomy in SOEs was largely associated with state intervention in enterprise affairs, even though separation of administrative functions from enterprise business had been a policy for at least a decade. He called for leaders to make a decisive move towards the removal of the administrative function from all SOEs.

The internal corporate governance group recommended either privatisation or divestiture. Many economists argued for modern enterprise institutions, with limited shareholding or limited responsibility corporations as the role models. Forming large company groups was also recommended as a way to increase international competitiveness (Macroeconomic Institution 1996). Wu (1993a) and Zhou et al. (1994) proposed to convert the state assets in SOEs to shares controlled by holding companies at various levels of government. The state would thus continue to dominate the former SOEs. Zhang (1995), on the other hand, recommended conversion of state assets into debts owed by SOEs (instead of shares). He suggested that this was not only costeffective (saving monitoring costs) but also guaranteed stable valueadding in these assets. Zhang further argued that a crucial element of SOE reform was to form a mechanism for selecting the best entrepreneurs to run the firms.

The competitive environment group paid particular attention to the unequal burdens and economic environment for SOEs. Lin et al. (1997) argued against changing SOEs' ownership structure because private ownership is neither a sufficient nor a necessary condition for an enterprise to be efficient. The essential step in China's SOE reform, they suggested, was to create a market environment in which enterprises with all kinds of ownership arrangements could compete with each other in a fair environment in which 'the fittest survives'. Therefore, the main task of SOE reform was to eliminate the existing policy-determined burdens on SOEs so as to create a level-playing field.

From 1994, the government started to adopt a flexible reform approach toward SOEs which was popularly characterised as 'emphasizing the big and liberalizing the small'. This strategy was officially implemented after its confirmation at the $15^{\text {th }}$ Party Congress in October 1997 and the $9^{\text {th }}$ National People's Congress in March 1998. In essence, the policy attempts to maintain about 1,000 large SOEs through the introduction 
of the 'modern enterprise institution', dominated by the shareholding system, and to privatise the small and medium-sized SOEs through selling, auctioning, merging and bankrupting.

The concept of 'modern enterprise institution' was defined officially to include four important aspects: clearly defined property rights; clear division of autonomy and responsibility; separation of administrative function from enterprise decisions; and scientific management. The dominant form of the new institution was the shareholding system. The government also attempted to alleviate large SOEs' policy-induced burdens. This involved lessening the burden for SOEs disadvantaged by excessive capitalisation, such as converting military plants into civil factories, further liberalising (or adjusting) prices for state-controlled products, such as coal, reducing SOEs' pension burden by building a new pension system, such as one along the lines of the governmentpreferred Singapore model, which combines contributions from enterprises and individuals, reducing the number of redundant workers by granting enterprises autonomy in employing and dismissing workers, and introducing a new policy, 'state investment for bank loans', to reduce the pressure on SOEs of interest payments.

The policy toward the small and medium-sized SOEs was more liberal. Spontaneous privatisation was, in fact, already underway. The 'Zhucheng model' provides a good example. In 1993, the Zhucheng city government began to establish shareholding companies for all of its SOEs by selling shares to enterprise employees (Zhucheng Municipality Government 1996). Before reform, 60 per cent of the 150 enterprises were in debt to the value of 147 million yuan; 30 SOEs suffered a loss of state assets of 100 million yuan. In 1993, the municipality government sold all its SOEs to enterprise employees. Similarly, Shunde City of Guangdong province offered a very similar 'Shunde model' (Shunde City Government 1997). With the removal of the ideological constraint on ownership reform, it is expected that privatisation of SOEs will accelerate.

\section{Assessment of enterprise performance}

\section{Total factor productivity}

There are two important issues about SOE production efficiency that are under dispute in the literature. The first issue is the size of total factor productivity (TFP) growth, assuming that there was indeed positive 
TFP growth. The second issue is whether this growth could be attributed to the specific reform measures that were implemented.

Researchers have found an amazingly wide range of TFP growth rates (see Table 5.2). The high TFP growth rate in Chen et al. (1988b) was based on downward adjustments of official data on labour and capital inputs. ${ }^{5}$ From the debate between Woo et al. $(1993,1994 a)$ and Jefferson et al. (1994), it appears that the high TFP growth rate in Jefferson et al. (1992) was the result of using input deflators that understated inputs. Groves et al. (1994) and Perkins and Raiser (1995), using input deflators constructed in the manner of Jefferson et al. (1992), also found high TFP growth rates.

There is now a growing body of literature reaching the opposite conclusion on productivity performance. Using data aggregated at the city level, Xiao (1991) found productivity in the state sector to be stagnant between 1985 and 1987. He also found a positive statistical relationship between the TFP growth of a city and its share of industrial output produced by non-state enterprises. Employing National Industrial Census data and applying various functional forms, McGuckin et al. (1992) uncovered significant negative TFP growth in China's state industry in the period 1980-84. Estimations by Woo et al. (1994b) on data from 300 SOEs established that TFP growth was zero at best during 1984-88. More recently, in a comparative analysis of Chinese industry using a survey data set of 967 SOEs, Huang and Meng (1997) found negative TFP growth for the SOEs during 1985-90.

It must be noted that some studies that found productivity improvement found that TFP growth declined over time. Wu and Wu (1994) found that TFP increased in the 1979-84 period but was stagnant in the 198592 period. Perkins et al. (1993) discovered that the TFP index for industrial SOEs rose from 100 in 1981 to 104 in 1985 and then declined steadily to 81 in 1989 .

In a recent study, Huang et al. (1998b) attempted to decompose the productivity growth into technological progress and technical efficiency for six sampled industries between 1980 and 1994. It was found that while productivity growth in these industries was in general not very significant, it was mainly achieved through improvements in technical efficiency, and technology largely stagnated.

Besides the disagreement on the actual TFP performance in the SOE sector, there is also an equally contentious debate over the fundamental issue of the actual contribution of reform policies to SOES' TFP 
performance. Groves et al. (1994) estimated direct links between productivity increases and a range of incentives offered to SOEs. It now appears, however, that these direct links were very tenuous ones.

Lee (1990) focused on three SOE reform measures-the contract management system, the managerial responsibility system and the internal contract system. Using a sample of 75 large and medium-sized steel SOEs in 1986, he concluded that the impact on output from any single reform measure was not significant. While the effects of some combinations of reform measures were significant, the magnitudes of the impacts were very small. ${ }^{6}$ Using data from 769 SOE surveys for 1980-89, Du and Guo (1995) looked at four particular indicators of reform - the proportion of raw materials purchased from the free market, the share of product marketed to the free market, the proportion of contracted workers in the total workforce, and the profit retention rate. They found that, while the coefficient estimate for the product marketing variable was statistically insignificant, the estimates for the other three policy variables were all significantly negative. Huang and Duncan (1997) identified a longer list of reform measures including market competition, and incentive and autonomy, and used data from 300 enterprises between 1980 and 1992. While they found that some measures contributed positively to SOEs' productive performance, the overall contribution of reform to TFP growth was negligible. ${ }^{7}$

\section{Table 5.2 Selected studies on TFP growth in China's SOEs}

\begin{tabular}{lrlr} 
Study & Period & Data set & $\begin{array}{c}\text { TFP growth } \\
(\%)\end{array}$ \\
& & & \\
Chen et al. (1988c) & $1978-85$ & National industry aggregate & $4.0-5.0$ \\
Dollar (1990) & $1979-82$ & 20 SOEs survey data & 1.2 \\
Jefferson et al. (1992) & $1984-87$ & City/county aggregate data & 2.4 \\
Perkins (1995) & $1980-90$ & 300 enterprises survey data & 2.7 \\
Li (1997) & $1980-89$ & 272 SOEs survey data & 4.7 \\
Xiao (1991) & $1985-87$ & City aggregate data & - \\
McGuckin et al. (1992) & $1980-84$ & National industrial census & $<0$ \\
Woo et al. (1994a) & $1984-88$ & 300 SOEs survey data & $\leq 0$ \\
Huang and Meng(1997) & $1986-90$ & 967 SOEs survey data & -2.2 \\
Huang et al. (1998b) & $1980-94$ & 800 SOEs survey data & 0.3 \\
& & & \\
\hline
\end{tabular}




\section{Profitability}

The financial performance of the state sector worsened sharply during the reform period. The total losses of industrial SOEs rose from 4.2 billion yuan in 1978 to 34.9 billion yuan in 1990 and 72.7 billion yuan in 1996-an astonishing annual growth rate of 17 per cent between 1978 and 1996 (SSB 1996, 1997). It is widely estimated that in the 1990s, about one-third of SOEs made explicit losses and another one-third made implicit losses (Liu 1996). In 1996, about half of the SOEs became money losers and the state sector as a whole faced a net deficit of 38 billion yuan (SSB 1997).

The poor financial performance of SOEs is not a controversial issue among economists, but the cause of it certainly is. Based on the perception that SOEs experienced positive TFP growth but rising lossmaking, Sicular (1995) suggested that SOE managers were hiding their profits. On the other hand, Naughton (1995) and Rawski (1995) have argued that the rising losses were a natural outcome of increased competition from the rising non-state sector, coupled with changes in government policies toward prices, taxation, depreciation and interest payments.

However, Fan and Woo (1996) have pointed out that the competition argument cannot explain why profitability fell across the board, even in heavy industry where there was negligible new entry, and in industries where prices had not fallen. Furthermore, if falling profitability in SOEs was the result of an increasingly competitive market, then similarly low profitability should have been observed in non-state sectors. The fact is that although collective and other (private and joint ventures) enterprises in $1996 \mathrm{had}$, on the average, assets about 67-70 per cent smaller than that of state enterprises, their profits were 18-23 per cent larger than those of state enterprises. ${ }^{8}$ The profit-asset ratios in non-state enterprises (3.1-3.2 per cent) were about four times those of SOEs (0.8 per cent) (SSB 1997).

Huang and Duncan (1999) investigated the empirical relationship between competition and profitability using enterprise survey data. They found no evidence to support a negative correlation. In a later study, Huang (1998b) suggested that the relationship between competition and profitability during economic transition was not the same as that in a conventional market. Increased competition could cause enterprise 


\section{Table 5.3 State-owned enterprise profits and real wages, 1985-96}

\begin{tabular}{cccccc}
\hline Year & $\begin{array}{c}\text { SOE net } \\
\text { profit } \\
\text { (billion yuan) }\end{array}$ & $\begin{array}{c}\text { Net value } \\
\text { of capital }\end{array}$ & $\begin{array}{c}\text { Profit- } \\
\text { capital rate } \\
(\%)\end{array}$ & $\begin{array}{c}\text { SOE/Collective (1978=100) } \\
\text { Real } \\
\text { wages }\end{array}$ & $\begin{array}{c}\text { Labour } \\
\text { productivity }\end{array}$ \\
1985 & 70.6 & 399 & 17.7 & 100.0 & 100.0 \\
1986 & 63.5 & 454 & 14.0 & 103.2 & 89.2 \\
1987 & 72.6 & 525 & 13.8 & 102.1 & 79.5 \\
1988 & 81.0 & 603 & 13.4 & 103.6 & 68.2 \\
1989 & 56.3 & 701 & 8.0 & 105.3 & 62.9 \\
1990 & 3.9 & 809 & 0.5 & 108.3 & 58.9 \\
1991 & 3.5 & 958 & 0.4 & 105.9 & 53.6 \\
1992 & 16.6 & 1092 & 1.5 & 108.7 & 44.1 \\
1993 & 36.5 & 1340 & 2.7 & 108.6 & 32.3 \\
1994 & 34.6 & 1564 & 2.2 & 117.8 & 26.0 \\
1995 & 12.5 & 1752 & 0.7 & 114.0 & 23.3 \\
1996 & -30.9 & 2088 & -1.5 & 120.7 & 19.8 \\
\hline
\end{tabular}

Sources: State Statistical Bureau, 1996, 1997. Statistical Yearbook of China, China Statistical Publishing House, Beijing.

profitability to fall or rise depending on the magnitudes of changes in output prices, input prices and input-output coefficients following the introduction of a free market.

Likely, the two fundamental reasons for the worsening financial performance of SOEs were stagnant (or declining) productivity and overspending on direct and indirect wages. This is partly indicated by the statistics in Table 5.3. Between 1985 and 1996, the relative wages of SOEs to collective enterprises increased by 21 per cent while their relative labour productivity declined by almost 80 per cent. This argument is also supported by a recent investigation of 2,000 loss-making SOEs by China's State Statistics Bureau, which showed that 9.1 per cent of SOEs made losses because of policy factors, 9.2 per cent made losses because of changes in the macroeconomic environment and 81.7 per cent made losses because of mismanagement and inefficiency (Tan 1996). 


\section{Macroeconomic implications}

The transition of SOEs has obviously contributed to the success of the Chinese economy in its own way. In the early stages of reform, the growing SOEs provided a base for firms that were developing outside the plan. In fact, many successful township and village enterprises (TVEs) started their businesses through sub-contracting from urban SOEs (Perkins 1999). The rapidly increasing demand for inputs by SOEs and for consumption goods by their employees provided expanding purchasing power for goods produced by the non-state sectors. Some SOEs themselves also improved productive efficiency through policy reforms and increased competition with non-state firms (Jefferson et al. 1992, 1996; Jefferson and Rawski 1994; Rawski 1994). Another important contribution by SOEs was the provision of a safety net for China's economic reform by containing the redundant workers within the factories (McMillan and Naughton 1992; Naughton 1995). This helped to create a stable socio-political environment for growth elsewhere in the economy.

While the safety net was particularly important, it is debatable whether the Chinese approach followed the most efficient path. The main function of the SOE 'safety net' was to keep redundant workers on an enterprise payroll is order to ensure social stability. It is true that China has a big unemployment problem, especially after taking into account surplus agricultural labour. But China also has a very dynamic non-state sector which created about 210 million new jobs between 1978 and 1996, almost double that of the total SOE workforce in 1996 (SSB 1997:27). ${ }^{9}$ In 1997, about 12 million workers were laid off by SOEs but these workers continued to receive a proportion of their wages and enjoy other welfare benefits. By the end of 1997, at least 6 million had found new jobs (Meng 1998). The re-employment problems in some regions in the short run cannot be denied, but a more efficient safety net would be provided by the pooling of enterprise welfare funds under the supervision of a social security system or the Ministry of Civil Affairs. Assuming the current average of 2,000 yuan per annum paid to each 
laid-off worker, the direct government subsidy to loss-making SOEs could easily support 16 million workers, ${ }^{10}$ and would not waste resources on producing unsaleable products.

Examination of the cost of the SOE 'safety net' is more complicated. Some proponents of the cushioning effect provided by SOEs recognised that it meant forcing consumers to buy low quality products for a while (McMillan and Naughton 1992). However, the negative impact of the safety net extend far beyond this.

Woo (1994) argued that the financial weakness of SOEs destabilised the economy through two channels. The first was through the state budget and the second through the banking system. At the beginning of economic reform, SOEs accounted for well above 80 per cent of total budget revenue; this ratio fell to about 60 per cent in the mid 1990s. The budget deficit increased from 8 billion yuan in the Sixth Five-Year Plan period (1981-85) to 59 billion yuan in the Seventh Five-Year Plan period (1986-90), and 195 billion yuan in the Eighth Five-Year Plan period (1991-95) (SSB 1997). SOEs contributed to this rapidly rising budget deficit in two ways: one related to the slow growth of revenue from the SOE sector and the other related to the increasing budget subsidies to SOEs. Direct subsidies to loss-making SOEs rose from 18.2 billion yuan-1.2 per cent of gross national product (GNP) -in 1988, to 84.4 billion yuan-2.4 per cent of GNP-in 1993 (Table 5.4). The widening budget deficit had historically tended to lead to faster monetary growth.

Yin (1995) also noted that SOEs were a constant source of inflationary pressure. He observed that whenever SOEs faced increased competition, they would intensify their lobby for credit, and monetary expansion would result, such as in the mid 1980s and early 1990s. Perkins and Raiser (1995) argued that 'China's high growth rate is at least partly attributable to fortuitous exogenous factors, while its tendency to reproduce costly inflationary episodes may be related to remaining budget softness for industrial state-owned enterprises' (Perkins and Raiser 1995:12).

SOE loss-making had significant implications for the banking system. When SOEs' losses could no longer be fully covered by the budget, they turned to the state banks. Because of the soft-budget constraint, SOE managers were always hungry for investment, regardless of their enterprises' financial performance (Kornai 1980). Their demands on the state banks for financing were often quite persuasive because their demands were couched in terms of the 'safety net' function and the 
ideological importance of state ownership. The result was that the state banks largely ignored the financing needs of the new, dynamic nonstate sector, and focused their lending on SOEs. In an empirical study using city data in the period 1989-91, Wei and Wang (1996) found that the higher a city's initial proportion of SOEs, the higher the growth rate of bank loans going to that city. In the industry as a whole, SOEs accounted for 74 per cent of investment, but produced only one-third of output in 1994 (World Bank 1996).

Perkins and Raiser (1995) estimated the amount of fiscal and banking system subsidies to SOEs between 1986 and 1992. ${ }^{11}$ Their lowest estimates showed that total subsidies to industrial SOEs rose from 6 billion yuan in 1980 to 268 billion yuan in 1992 . The latter amounted to approximately 10 per cent of GNP in 1992. To realise the enormity of the resource cost, one should note that the total value added by industrial SOEs was only about 14 per cent of GDP in 1996 (SSB 1997:42, 428).

Table 5.4 Losses and subsidies to SOEs in China (billion yuan)

\begin{tabular}{|c|c|c|c|c|c|c|c|c|}
\hline & 1980 & 1986 & 1988 & 1990 & 1991 & 1992 & 1993 & 1996 \\
\hline $\begin{array}{l}\text { Losses of } \\
\text { industrial SOEs } \\
\text { Direct subsidies }\end{array}$ & 3.4 & 5.5 & 8.2 & 34.9 & 36.7 & 36.9 & 45.3 & 72.7 \\
\hline to deficit SOEs & . & & 18.0 & 12.4 & 57.9 & 50.6 & 84.4 & .. \\
\hline Ratio to GNP $(\%)^{c}$ & .. & & 1.2 & 0.7 & 2.7 & 1.9 & 2.4 & .. \\
\hline \multicolumn{9}{|c|}{ Estimated subsidies to industrial SOEs ${ }^{d}$} \\
\hline Fiscal subsidy & 5.4 & 34.5 & 48.2 & 111.8 & 114.7 & 167.2 & .. & .. \\
\hline Monetary subsidy & 0.9 & 28.7 & 42.3 & 51.8 & 85.9 & 100.5 & .. & .. \\
\hline Total subsidy & 6.3 & 63.3 & 90.5 & 163.6 & 200.6 & 267.7 & .. & .. \\
\hline Ratio to GNP (\%) & 1.4 & 6.2 & 6.1 & 8.8 & 9.3 & 10.0 & 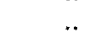 & \\
\hline Budget deficita & -6.9 & -8.3 & -13.4 & -14.7 & -23.7 & -25.9 & -29.3 & -54.8 \\
\hline Ratio to GNP (\%) & -1.5 & -0.8 & -0.9 & -0.8 & -1.1 & -1.0 & -0.8 & .. \\
\hline
\end{tabular}

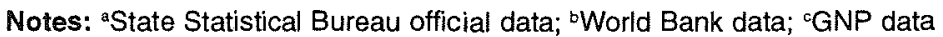
used in this table all from State Statistical Bureau; dPerkins and Raiser (1995) estimates at bond rate.

Sources: State Statistical Bureau, 1997. Statistical Yearbook of China, China Statistical Publishing House, Beijing; World Bank, 1995. Reform and the Role of the Plan in the 1990s, World Bank Country Study, Washington, DC;

Perkins, F. and Raiser, M., 1995. State Enterprise Reform and Macroeconomic Stability in Transitional Economies, Economic Division Working Papers, Development Issues 95/1, Research School of Pacific and Asian Studies, The Australian National University, Canberra. 


\section{Concluding remarks}

China's state sector is yet to achieve its full success, considering its productivity growth and financial performance. But the fact that SOEs did not collapse at the beginning of the reform period shows that they were an important facilitator of China's rapid growth in the following two decades, especially outside the plan system. This role of facilitation came at a cost in terms of fiscal burden, inefficiency in resource allocation, vulnerability of the financial sector and macroeconomic instability.

While the approach of reform without changing the ownership structure might have been favourable during the initial period, property rights reform is now long overdue. It is hard to determine the exact point in time when the Chinese government should have switched its SOE reform approach. But statistics suggest that the overall outcome would be much better if the switch had taken place in the late 1980 s or early 1990 s. It was after that time that enterprise performance worsened significantly both in terms of productivity and profitability. The reasons for the dramatic change were complicated and were probably a mixture of the following

- widespread excess capacity

- completion of the contract system reform

- development of the market system and intensified competition.

From the early 1990 s, SOEs became more a burden than a positive contributor. Most SOEs had accomplished their historical responsibilities.

The cost of the inefficient SOE sector has now been fully recognised by the government, which announced a radical policy in 1998 to complete the reform of SOEs within three years following the principle of liberalising the small and emphasising the big'. The government intended to retain about 1,000 large SOEs in key industries and privatise more than 300,000 small and medium-size SOEs through leasing, shareholding, auctioning, merging and bankrupting. This means that both the ownership reform and non-ownership reform approaches, focusing on internal organisational structure and market environment, are adopted.

In 1998, affected by the East Asian financial crisis and weak domestic demand, the pace of SOE reforms slowed significantly. Rapid economic growth and thus fast new job creation, are a critical condition for SOE reform. Both external crises and deflationary effects bite hard on economic growth. In order to achieve its 8 per cent GDP growth target, the government introduced an expansionary fiscal policy to stimulate growth. While China failed only marginally to achieve the growth target, 
the jobs created by these new infrastructure projects did not help to ease urban unemployment pressure. The economic situation in 1999 and 2000 will probably be much the same. It is likely that China needs more than three years to complete its reform of SOEs.

Apart from the necessary conditions for SOE reform, such as new jobs and a social security system, the government also needs to think more carefully about the transformation of SOEs. While it is reasonable for the government to retain a number of large SOEs in the critical industries for the stability of the national economy, it must be recognised that monopolies do not usually deliver an efficient outcome. Alongside further changes to the management structure of these SOEs, introduction of market competition is the key to improving efficiency. Without transforming them into true market entities (with or without state ownership), including the complete elimination of the soft-budget constraint problem, SOEs can never perform efficiently. Lessons must be drawn from the Japanese keiretsu and the Korean chaebol, especially after the East Asian crisis.

Reform of the small and medium-size SOEs is easier and it can be expected that the pace of privatisation of these firms will be accelerated once China's macroeconomic situation improves. A more crucial issue, however, is how to ensure a favourable environment once they are privatised. The current resource allocation system which discriminates against non-state-especially private-firms must be corrected.

Zhu Rongji was right in coordinating the reform tasks in a single package, since the problems are closely related, especially fiscal, enterprise and financial problems. Some dramatic measures may also be needed, because Chinese reform proceeded in such a way as to tackle the easy tasks first and leave the difficult ones for later. But radical reform is neither in China's tradition, nor is it an easy task. Given the difficulties of the reform tasks and the structure of the political economy, it will probably take a few more years for China to accomplish SOE reform and reforms in other areas.

\section{Notes}

"This paper draws on earlier joint works with Ron Duncan, Fang Cai, Wing Thye Woo and K.P. Kalirajan. The author benefited from discussions with Weiying Zhang, Chunlin Zhang, Wenquan Yiin, Xuedong Ding, Justin Yifu Lin, Hongling Wang, Zuoyuan Zhang, Yongzheng Yang and Thomas Rawski. Funding for research was by the Australian Agency for International Aid (AusAID) and is gratefully acknowledged. 
${ }^{1}$ Both Gu and Sun were later purged for their right-wing views.

${ }^{2}$ In reality, however, doing so was difficult as many contractors of poorly performing SOEs were not able to deliver the required amount of profits to the state.

${ }^{3}$ Small SOEs in this context were defined as firms with fixed assets of 5 million yuan and profits of 500 thousand yuan in Beijing, Tianjin and Shanghai; fixed assets of 4 million yuan and profits of 400 thousand yuan in fourteen independently planned cities; and fixed assets of 3 million yuan and profits of 300 thousand yuan in all other regions ( $X \mathrm{U}$ and $\mathrm{Li} 1996$ ).

${ }^{4}$ On the other hand, the contractors also faced social pressures if they pocketed the large rewards defined in the contracts (Dong and Tang 1992).

${ }^{5}$ Lau and Brada (1990) also found high positive TFP growth, but this is to be expected because they used the reconstructed data of Chen et al. (1988c).

${ }^{6}$ All three studies by Lee (1990), Du and Guo (1995) and Huang and Duncan (1997) applied value-added/gross output production functions. Specific reform measures were then included as additional explanatory variables for examination of their contribution to output and productivity.

7 There was substantial TFP growth in the Huang and Duncan (1997) study because they employed an input deflator constructed in the manner of Jefferson et al. (1992).

${ }^{8}$ These were based on the profits of each sector, ignoring losses by deficit firms. The net profits for state, collective and private sectors were, respectively, -31, 24 and 26 billion yuan in 1996 (SSB 1997).

${ }^{9}$ This has not taken into account a large number of labour migrants not registered with the government.

${ }^{10}$ According to Perkins (1999), direct government subsidies to SOES was 32.2 billion yuan in 1995 .

${ }^{11}$ In calculating the direct and indirect subsidies, they used both the government bond rate and international interest rate to capture the financial cost of capital to the Chinese government and the economic opportunity cost of capital to China respectively. 